\title{
Disputed Territories and the Law on the Use of Force: Lessons from the Eritrea-Ethiopia Case
}

Constantinos Yiallourides, British Institute of International and Comparative Law (BIICL), London, United Kingdom. Email: c.yiallourides@BIICL.org

Zeray Yihdego, University of Aberdeen, United Kingdom. Email: Zeray.yihdego@ abdn.ac.uk

\begin{abstract}
On 19 December 2005, in its partial award, the Eritrea-Ethiopia Claims Commission found that Eritrea had acted in violation of the rules of international law on the use of force (jus ad bellum) in resorting to armed force to attack and occupy the disputed border town of Badme and surrounding areas, which were then under the peaceful administration of Ethiopia. In its award, the Claims Commission made a number of important findings which, taken with the EritreaEthiopia Boundary Commission's 2002 decision on boundary delimitation, contribute towards informing and clarifying the substance of international law applicable to disputed territories and the legal obligations of states acting in those areas, especially where the use of force is engaged. This article examines the Claims Commission's jus ad bellum award and concentrates on three key issues: a) the legality in international law of the resort to force as a means of gaining control over territory to which a state has (or believes that it has) a valid sovereignty title; b) the specific contours of self-defence in relation to territorial sovereignty claims, and c) the legitimacy of dealing with use of force issues by arbitral tribunals. In September 2018, the leaders of the two countries signed a peace and friendship agreement, thus, setting course for a new era of peace and cooperation. The lessons that ought to be learnt by these two neighbouring countries and other states have been articulated as concluding remarks.
\end{abstract}




\section{Introduction}

Eritrea was part of the Aksumite Kingdom, the foundation of the ancient empire of Abyssinia, now the Ethiopian State, up until 1890, the year when Italy proclaimed Eritrea as its colony. ${ }^{1}$ Despite the defeat of Italy by Ethiopia at Adowa in 1896, Eritrea remained in the hands of the Italians until 1941 when Britain took over and administered the territory as a United Nations (UN) trustee. Eritrea became part of Ethiopia in 1952 pursuant to General Assembly Resolution 390A(V). ${ }^{2}$ It declared its independence in 1993 following a civil war that lasted almost thirty years. ${ }^{3}$ Ethiopia (with current population about 105 million) and the newly-independent State of Eritrea (with current population about 5 million) enjoyed stable socio-economic and security relations until a number of border incidents erupted in 1998 near the town of Badme. These incidents led to the deployment of Eritrean armed forces to Badme and its environs which, in turn, triggered a declaration of self-defence by the Ethiopian Parliament on 13 May $1998 .{ }^{4} \mathrm{~A}$ large-scale war between the two countries erupted inflicting devastating harm on both sides. ${ }^{5}$ The Eritrea-Ethiopia Claims Commission was established subsequently to assess all claims for loss, damage or injury by one state against the other resulting from violations of international law. It concluded that Eritrea's action to forcibly reclaim Badme and other territories, which were then under the peaceful administration of Ethiopia, constituted a violation of Article 2(4) of the UN Charter on the prohibition of the use of force. ${ }^{6}$ As a consequence, Eritrea was liable to compensate Ethiopia for the damages caused by this violation of international law. ${ }^{7}$

In its award, the Claims Commission made a number of important findings which, taken with the Eritrea-Ethiopia Boundary Commission's 2002 decision on boundary delimitation,

\footnotetext{
1 The Kingdom of Aksum existed during the first seven (although others submit nine) centuries AD in Northern Ethiopia. Its rule and power influence encompassed modern Yemen, Somalia and Djibouti. It adopted Christianity in the $4^{\text {th }}$ Century AD, introduced, and used its own language called $G e ' e z$. This ancient civilisation was a dominant trading empire in the Red Sea until the end of the ninth century, see Phillipson (1998) 1-55.

2 General Assembly Resolution 390A(V) (2 December 1950) https://documents-ddsny.un.org/doc/RESOLUTION/GEN/NR0/059/88/IMG/NR005988.pdf?OpenElement

${ }^{3}$ On the history of the Ethiopian region see Marcus (2002); Zewde (1998).

${ }^{4}$ The Declaration called upon Eritrea 'immediately' and 'unconditionally' to withdraw its army from Ethiopian controlled territories, 'Letter dated 20 December 2005 from the Charge d'affaires a.i. of the Permanent Mission of Ethiopia to the United Nations addressed to the President of the Security Council' 3 <https://www.securitycouncilreport.org/atf/cf/\%7B65BFCF9B6D27-4E9C-8CD3-CF6E4FF96FF9\%7D/EE\%20S2005816.pdf>.

5 The war lasted two years and involved the deaths of 70,000 soldiers and the displacement of over a million civilians. Government spending had been diverted to the arms race. Drought and famine seriously aggravated the situation causing a large humanitarian crisis, Gray (2006) 702-704; In addition, one of the consequences of this conflict was its spillover effect on the conflict in Somalia. Ethiopia and the UN accused Eritrea of supporting Al-Shabaab or other Islamises; Eritrea denied such accusations, see Yihdego (2007) 666-676; see also Cliffe (1999) 89-111.

${ }^{6}$ Eritrea-Ethiopia Claims Commission, Partial Award, Jus ad Bellum: Ethiopia's Claims 1-8 (19 December 2005). The Claims Commission was composed of Hans van Houtte (President), George H Aldrich, John R Crook, James C N Paul, and Lucy Reed.

${ }^{7}$ ibid, para 16.
} 
contribute towards informing and clarifying the substance of international law applicable to disputed territories and the legal obligations of states acting in those areas, especially where the use of force is engaged.

This article discusses the interplay between disputed territories and the law on the use of force by looking at how the Claims Commission applied the rules of jus ad bellum to the EritreaEthiopia territorial dispute. It focuses on three main issues: a) the legality in international law of the resort to force as a means of gaining control over territory to which a state has (or believes that it has) a valid sovereign title; b) the specific contours of self-defence in relation to territorial sovereignty claims, and c) the legitimacy of dealing with use of force issues by arbitral tribunals. The lessons that ought to be learnt by these two neighbouring countries, in the light of recent developments in the relations between them, and other states involved in disputes over territory are articulated as concluding observations.

\subsection{Factual background: Who started the war and why?}

The two sides took different views as to who began the war in the first place. ${ }^{8}$ The Ethiopian version was that the conflict erupted when Eritrean soldiers entered Ethiopian controlled territories without any legal justification and later attacked and occupied the border town of Badme and adjacent areas, all of which were controlled and administered at the time by Ethiopia. According to Ethiopia, Eritrea's action warranted a forcible counteraction in selfdefence to regain control over the territory that Eritrea had managed to occupy. ${ }^{9}$ On its part, Eritrea contended that Ethiopia was illegally occupying Badme and sought to correct this perceived injustice by reclaiming the territory by force. ${ }^{10}$ This seemingly geographicallyisolated border friction, which might have been caused by various other factors discussed later in this piece, quickly escalated to a full-scale war between the two states.

After a series of offensives and counter-offensives involving the military forces of the two states that lasted for nearly two years and following the advancement of Ethiopian troops to many parts of Eritrea, the two parties negotiated and concluded the 2000 Algiers Agreement

\footnotetext{
${ }^{8}$ For a detailed factual background to the Eritrean-Ethiopian armed conflict 1998-2000, see Gray (2006) 700-704; Murphy, Kidane and Snider (2013) Ch 1; Murphy (2018) 552-572; A de Guttry and others (2009) 109-223.

${ }^{9}$ Eritrea-Ethiopia Claims Commission, Partial Award, Jus ad Bellum: Ethiopia's Claims 1-8 (19 December 2005); Murphy, Kidane and Snider (2013) 16.

${ }^{10}$ Murphy, Kidane and Snider (2013) 30.
} 
which officially, but not in reality, ended the Eritrea-Ethiopia war. ${ }^{11}$ Pursuant to the 2000 Algiers Agreement, the parties undertook to carry out four main tasks. First, to 'permanently terminate military hostilities' and respect humanitarian law in treating prisoners of war and civilians. Second, to investigate and determine the causes of the conflict. Third, to award damages for violations of international law. Fourth, to delimit and demarcate their boundaries on the basis of international law through the establishment of a Boundary Commission. ${ }^{12}$

The first task, to terminate hostilities and respect humanitarian law, largely succeeded. ${ }^{13}$ The United Nations Mission in Ethiopia and Eritrea (UNMEE) was established pursuant to Security Council Resolution 1312/2000 with the mandate to monitor the cessation of hostilities until the delimitation and demarcation of the border are completed. ${ }^{14}$ The Mission was terminated on 30 July 2008 by UNSC resolution 1827 because of the 'crippling restrictions imposed by Eritrea on UNMEE', amongst other reasons. ${ }^{15}$

The second commitment, to investigate the causes of the conflict, was never carried out. ${ }^{16}$ However, the third and fourth components of the 2000 Algiers Agreement led to the decisions of the Boundary Commission and the Claims Commission. ${ }^{17}$

The Boundary Commission rendered its unanimous decision on delimitation on 13 April 2002. ${ }^{18}$ It found that the colonial treaties concluded between Italy and Ethiopia in 1900, 1902 and 1908 determined the course of the boundary line between the two states and awarded Badme to Eritrea [see Figure 1], despite the fact that Ethiopia had exercised administrative

$11 \quad$ Art $1, \quad$ 'Ethiopia/Eritrea $\quad$ Peace Agreement' <https://peacemaker.un.org/sites/peacemaker.un.org/files/ER\%20ET_001212_AgreementEritreaEthiopia.pdf>; A situation of "no war, no peace' prevailed for the following years, see Woldemariam (2018) 407-427.

12 ibid, Arts 3-5.

${ }^{13}$ For a detailed account, see Woldemariam (2018) 407-427.

14 S/RES/1312 (31 July 2000); see 'United Nations Mission on Ethiopia And Eritrea' <https://unmee.unmissions.org/mandate>.

15 ibid.

${ }^{16}$ Article 3 of the Algiers Agreement provided for the creation of an independent body tasked with the investigation of "the origins of the conflict'. ${ }^{16}$ This body was never constituted by the UN Secretary-General, nor by either the Organisation of African Unity (OAU) or its successor, the African Union, see Gray (2006) 703; Murphy, Kidane and Snider (2013) 23; Murphy (2018) 557.

${ }_{17}$ Article 4 of the Algiers Agreement provided for the creation of a neutral Boundary Commission ('the Boundary Commission') charged with delimiting and demarcating the parties' land border in accordance with pertinent colonial treaties and applicable international law; Article 5 of the Algiers Agreement provided for the establishment of a neutral Claims Commission ('the Claims Commission') 'with the mandate to decide through binding arbitration all claims for loss, damage or injury by one State against the other resulting from violations of international law'.

18 Eritrea-Ethiopia Boundary Commission, Decision Regarding Delimitation of the Border (13 April 2002) $<$ http://legal.un.org/riaa/cases/vol_XXV/83-195.pdf>; UN Security Council, 'Special Report of the Secretary-General on $\begin{array}{lllll}\text { Ethiopia and } & \text { Eritrea’ } & \text { December } & \text { 2016) } & \text { S006/992 }\end{array}$ $<$ https://reliefweb.int/sites/reliefweb.int/files/resources/10E68923496B29C049257252000457C4-Full Report.pdf>. 
authority over Badme for a considerable period of time. ${ }^{19}$ According to the Boundary Commission, the evidence of Ethiopian administration of Badme and adjacent areas was 'not sufficiently clear in location, substantial in scope or extensive in time to displace the title of Eritrea that had crystallised as of $1935^{,} .^{20}$

The Claims Commission dealt with various aspects of international law including with jus in bello (international humanitarian law (IHL) ${ }^{21}$ and jus ad bellum (the rules of international law on the use of force). ${ }^{22}$ The Claims Commission concluded that Eritrea's action to forcibly reclaim Badme and other territories, which were then under the peaceful administration of Ethiopia, constituted a violation of Article 2(4) of the UN Charter on the prohibition of the use of force. ${ }^{23}$ The focus of this paper is on this particular aspect of the decision.

\subsection{Boundary and territorial questions not the only cause of the war}

The two states were in fundamental disagreement as to the origins and deeper roots of the war. The Eritrean side focused on its territorial rights, particularly after the occupation of some Eritrean territories following the successful counter-offensive by the Ethiopian defence forces. Ethiopia, for its part, argued that the main cause of the war was the Eritrean aggression caused by a desire to dominate the Ethiopian economy, not Eritrea's desire to advance its territorial sovereignty claims. What was clear with respect to the pre-war events was that the two states were having serious and multifaceted confrontations around currency, movement of goods and businesses across their borders and on related policy issues that were of crucial importance to their national interests. It has to be mentioned that Ethiopia and Eritrea shared the same currency until a few months prior to the waging of the war, the Ethiopian Birr. When Eritrea

\footnotetext{
${ }^{19}$ Murphy (2018) 553; Plaut (1999) 59; It has to be noted, however, that Badme was not the only contentious area of the boundary delimitation award. There were territories on other fronts of the border that have been awarded to Eritrea and Ethiopia that were also hotly contested by both parties. Clearly, Badme has become the flashpoint for legal, political, military, and purely symbolic reasons but was not the only point of disagreement with respect to the delimitation award.

${ }^{20}$ Eritrea-Ethiopia Boundary Commission, Decision Regarding Delimitation of the Border (13 April 2002) para 9.95.

${ }^{21} \mathrm{IHL}$ is the branch of international law that regulates the behaviour of warring parties during armed conflict and aims to promote humanity, distinction between civilians and combatants and civilian and military targets, necessity and proportionality, amongst others, see Green (2008).

${ }^{22}$ In contrast to IHL, the law on the use of force prohibits the threat or use of force by a State against another State as a tool of national or international policy. The primary legal source of this field of law is Article 2(4) of the UN Charter and customary international law. However, two key exceptions exist to the ban on the use of force: a) the inherent right of States to selfdefence when there is a prior armed attack launched against them as expressly recognised under Article 51 of the UN Charter and customary international law and; b) a use of force authorised by the UN Security Council; for an analysis, see Gray (2018) Chapters 2 and 4.

${ }^{23}$ Eritrea-Ethiopia Claims Commission, Partial Award, Jus ad Bellum: Ethiopia's Claims 1-8 (19 December 2005). The Claims Commission was composed of Hans van Houtte (President), George H Aldrich, John R Crook, James C N Paul, and Lucy Reed.
} 
introduced its own currency, the Nakfa in 1998, Ethiopia proposed the use of the US dollar as a medium of exchange, with which Eritrea was not happy. Such economic, monetary and trade issues were publicly stated as grounds of contention by officials and leaders of the two states, but less so boundary and territorial issues. ${ }^{24}$ Some authors have suggested that the underlying roots of the conflict can be found in the Eritrean and Ethiopian divergent approaches to democracy, government, and state building and their competition for hegemonic control within the former Ethiopian polity, rather than a mere boundary dispute. ${ }^{25}$ However, when the war began between the two countries, the rhetoric and nature of the conflict shifted almost exclusively to boundary and territorial issues.

It may well be that the war had multiple causes, and coming up with a single primary cause would prove to be difficult. According to Lencho Lata:

Picking the most pivotal one/ones from among the array of the conflict's stipulated causes also looks quite daunting. Border dispute, economic issues, the divergence of the ideologies of the groups ruling the two entities, differing visions and nature of state types, the contrast between democracy in one state and authoritarianism in the other, etc. are offered as some of the causes. But which one or ones is/are decisive, the resolution of which would pave the way for addressing all others? ${ }^{26}$

The interview given by the President of Eritrea with ERi-TV on 3 November 2018, aligns with such characterisation of the causes of the conflict. The first point President Afeworki made was that 'the Badme issue is an invention'; it was a cause neither for the war nor for the unfriendly relations between the two neighbouring countries. ${ }^{27}$ The second point he made, which is more difficult to corroborate, is that the border and Badme issues were part of an international ploy (particularly by the United States) to 'corner' and 'sanction' Eritrea by inventing border issues with Yemen, Djibouti and later with Ethiopia. ${ }^{28}$

Leaving the merits of such assertions to political scientists, we would like to emphasise that the cause of the Eritrea-Ethiopia war was not merely boundary and territorial issues, although the incidents in and around the border town of Badme do seem to have triggered the devastating

\footnotetext{
${ }^{24}$ As Plaut and Gilkes (1999) explain:

Occasional disputes did occur along the entire Ethiopian-Eritrean border after 1991. Most were local and small-scale. They were the sort of conflicts that frequently flare up along any ill-defined border which is straddled by farming communities. Low-level meetings between local officials took place in an attempt to resolve these matters, but when these failed the problems were referred upwards.

${ }^{25}$ Dias (2008) 53-64; see also Gilkes and Barry (2005).

${ }^{26}$ Lata (2003) 369.

${ }^{27}$ Interview with President Isaias Afwerki (3 November 2018) 〈https://www.youtube.com/watch?v=FUWQG6X1EDo> (rough translation from Tigrigna to English by author).

${ }^{28}$ ibid.
} 
1998-2000 war by escalating the tension and animosity over economic and political mis-trust between the two countries. ${ }^{29}$

The following section looks at the interplay between disputed territories and the law on the use of force in general before turning to the specific contours of the Eritrea-Ethiopia Claims Commission's award on jus ad bellum.

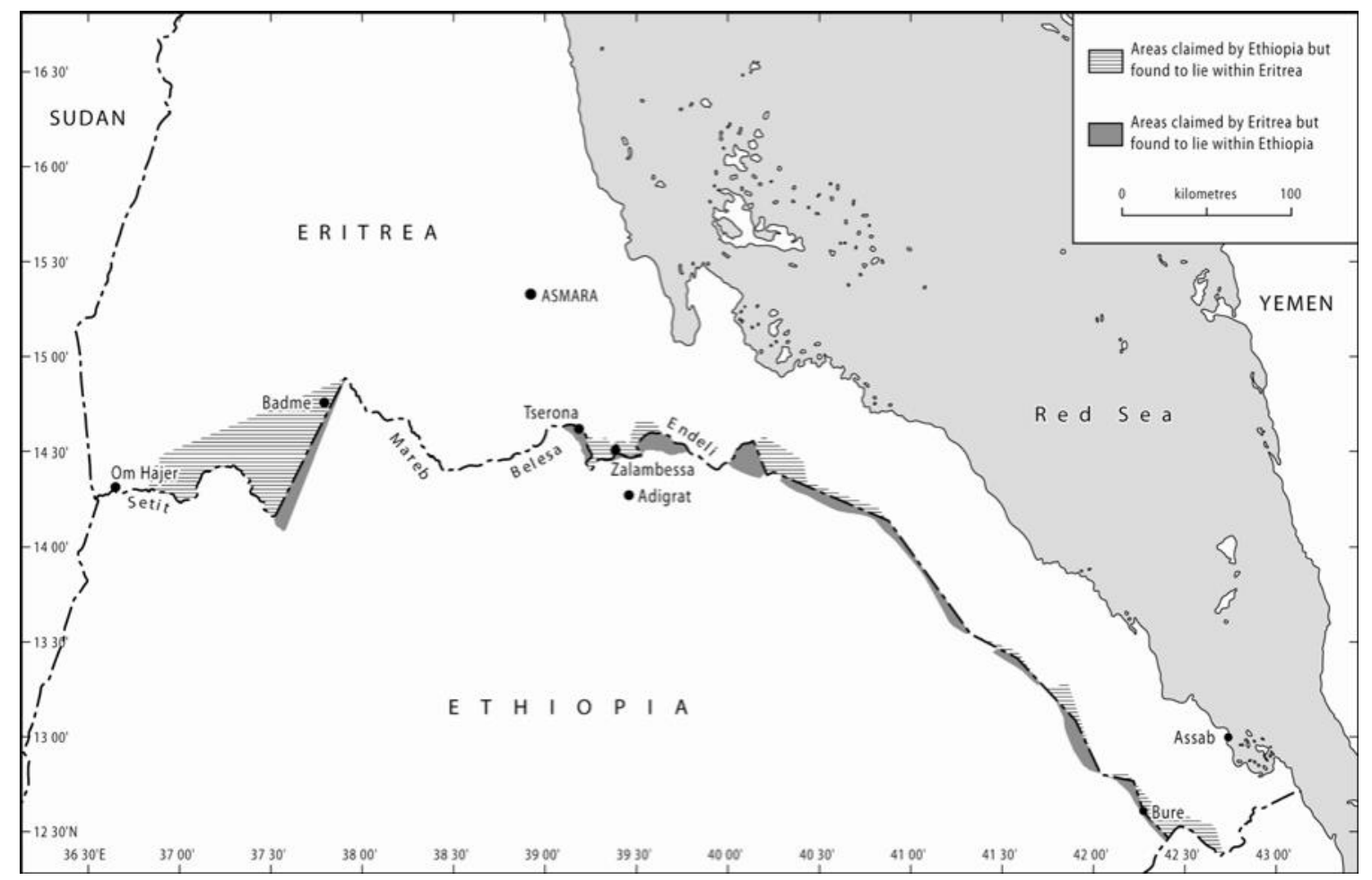

Figure 1: Eritrea-Ethiopia Border Area

Source: T Lyons, 'Avoiding Conflict in the Horn of Africa U.S. Policy Toward Ethiopia and Eritrea' (Council on Foreign Relations, 2006). Copyrighted to International Boundaries Research Unit, Durham University, www.dur.ac.uk/ibru.

\section{Disputed territories and the law on the use of force}

Few issues have become the focus of such heated contestation, conflict, and armed conflict amongst states than the determination of disputed claims of territorial sovereignty and disputes over the determination of territorial boundaries (generically referred to in this paper as 'territorial disputes'). ${ }^{30}$ There are four key factors behind the escalation of territorial disputes;

${ }^{29}$ ibid, p 50.

30 'A territorial dispute can be defined as a legal dispute between two or more States over the acquisition or attribution of territory (continental or island), or to the creation, location and effect of territorial boundaries', Yiallourides, Gehring and Gauci (2018) 3-4; On the distinction between 'boundary disputes', 'delimitation disputes', and 'territorial disputes' more 
a) strategic importance of the disputed land, b) economic importance, c) ethnic, cultural or religious reasons, and d) unsettled border lines following inter-state conflict ${ }^{31}$. Geographical factors are vastly important in influencing the outbreak of territorial disputes, with studies revealing that disputes tend to escalate more frequently between contiguous countries; anxieties regarding security breaches are naturally higher between such states, and proximity also provides more ample opportunity for physical occupation of land. ${ }^{32}$ As shown in this case study, moreover, other factors such as symbolic, economic and political factors might also play a role in causing territorial tensions and legal disputes.

In international law, sovereignty constitutes the ultimate authority over a territory. ${ }^{33}$ Territorial boundaries define the spatial limits of a state's sovereignty, namely, those geographical areas over which sovereignty may be exercised to the exclusion of all other states. ${ }^{34}$ The fundamental norms of sovereignty and territorial integrity enable a state with sovereignty over a given territory to act freely upon that territory and to prevent other states from acting upon it. The same norms protect the sovereign state from unilateral territorial incursions and violations of its territorial boundaries by other states. ${ }^{35}$

But what if that state's territorial boundaries are disputed by another state and there is no clear answer as to which state has sovereignty over the territory in question? In practice, states may disagree over the definition of the course of a land boundary (i.e. delimitation) or over the way it is positioned on the ground (i.e. demarcation). ${ }^{36}$ At some point, the exact course of their boundary has to be settled for the territory in question to be attributed; until then the essential basis for the protection of sovereignty, namely a title to territory, remains obscure. This raises several important legal questions, the foremost of which and indeed the crux of the EritreaEthiopia jus ad bellum award being: Can a state legitimately reclaim the disputed territory by

broadly, see Prescott and Triggs (2008) 138-140; Sharma (1997) 21-8; Cukwurah (1967) 6; Hill (1945) 25; Thirlway (2018) 117.

31 The Hague Centre for Strategic Studies, 'Pushing the Boundaries: Territorial Conflict in Today's World' (2015) 21.

32 Diehl, 'Territorial Disputes' (2008) 2083.

${ }^{33}$ Besson defines sovereignty as the 'supreme authority within a territory' pursuant to which States can enjoy 'the plenitude of internal jurisdiction, their immunity from other States' own jurisdiction and their freedom from other States' intervention on their territory (Art. 2 (4) and (7) UN Charter), but also their equal rank to other sovereign States', Besson (2007) paras 12 .

34 ' $[\mathrm{O}]$ ne of the essential elements of sovereignty is that it is to be exercised within territorial limits, and that, failing proof to the contrary, the territory is co-terminous with the Sovereignty', North Atlantic Coast Fisheries Case (1910) 948; see also Shaw (1986) 1-11.

${ }^{35}$ Island of Palmas Case (1928) 829; Bernárdez (1987) 487-94; Territorial integrity constitutes, according to the ICJ, 'an essential foundation of international relations' and 'an important part of the international legal order', Corfu Channel [1949] para 35; Kosovo Advisory Opinion [2010] 403.

${ }^{36}$ Yiallourides, Gehring and Gauci (2018) 3-4. 
force on the basis that it has a valid sovereignty title over that territory? Whichever way it is addressed, this question has far-reaching practical implications on a number of areas of international law, extending beyond the possibility of self-defence, to the possibility of countermeasures and the law relating to state responsibility.

\section{The Eritrea-Ethiopia Claims Commission's award on jus ad bellum.}

\subsection{Legal positions of the parties}

As mentioned earlier, the Eritrea-Ethiopia Claims Commission was established pursuant the 2000 Algiers Agreement which terminated the Eritrea-Ethiopia armed conflict. ${ }^{37}$ During the proceedings, Ethiopia claimed that, beginning 12 May and throughout June 1998, Eritrea carried out a series of armed attacks against Ethiopian territory in violation of Article 2(4) of the UN Charter. ${ }^{38}$ According to Ethiopia, Eritrea was responsible for initiating the conflict. ${ }^{39}$

Eritrea did not deny its forcible conduct but sought to justify it on the basis of self-defence, pursuant to Article 51 of the UN Charter. ${ }^{40}$ Specifically, Eritrea put forward three alternative legal grounds to justify its actions. First, that Ethiopia was unlawfully occupying Eritrean territory in the area around Badme (citing the decision of the Eritrea-Ethiopia Boundary Commission of 13 April 2002 which awarded Badme to Eritrea) and therefore Eritrea was justified in using military force to defend its territory. In essence, Eritrea argued that because it was correct in May 1998 that Badme was part of Eritrea, it was justified in using force to seize Badme and expel Ethiopian troops. ${ }^{41}$ Second, that Eritrea's action was in response to Ethiopia's 'forcible incursions' into Eritrean territory along the border area in early May 1988. ${ }^{42}$ Third, that it was Ethiopia that had commenced the conflict by issuing a war declaration on 13 May 1998 and therefore Eritrea was permitted to use military force against Ethiopia. ${ }^{43}$

\footnotetext{
${ }^{37}$ Art 1, 'Ethiopia/Eritrea Peace Agreement' (2000).

38 ibid, paras 6-8.

${ }^{39}$ Murphy (2018) 563.

${ }^{40}$ Eritrea-Ethiopia Claims Commission, Partial Award, Jus ad Bellum: Ethiopia's Claims 1-8 (19 December 2005) para 9.

${ }^{41}$ Murphy (2018) 561.

${ }^{42}$ Whilst Eritrea claimed that the armed incidents occurred within Eritrean territory, Ethiopia asserted that they occurred within Ethiopian territory, Eritrea-Ethiopia Claims Commission, Partial Award, Jus ad Bellum: Ethiopia's Claims 1-8 (19 December 2005) para 9.

43 ibid, para 9.
} 


\subsection{Main findings of the Claims Commission}

The Claims Commission rejected Eritrea's arguments on self-defence. As regards Eritrea's first line of argument, that its forcible takeover of Badme and other areas was a lawful measure of self-defence because it was territory to which Eritrea had a valid claim, the Claims Commission held that 'self-defense cannot be invoked to settle territorial disputes'. ${ }^{44}$ According to the Claims Commission, the boundary lacked demarcation and the parties clearly had differing interpretations as to the location of the border. But the existence of a disputed territory could not condone the illegality of Eritrea's recourse to military force. ${ }^{45}$ It held that:

[B]order disputes between States are so frequent that any exception to the prohibition of the threat or use of force for territory that is allegedly occupied unlawfully would create a large and dangerous hole in a fundamental rule of international law. ${ }^{46}$

In relation to Eritrea's second line of argument, that recourse to the use of force was lawful action in self-defence in response to Ethiopia's armed incursions into Eritrean territory in early May 1998, the Claims Commission found the requirements of self-defence had not been satisfied.

According to the Claims Commission, 'the predicate for a valid claim of self-defense under the UN Charter is that the party resorting to force has been subjected to an armed attack. ${ }^{47}$ Based on the evidence at hand, viewed in this particular context, the incidents that predated Eritrea's armed action along the border involved 'geographically limited clashes between small Eritrean and Ethiopian patrols along a remote, unmarked, and disputed border', which 'were not of a magnitude to constitute an armed attack by either state against the other within the meaning of Article 51 of the UN Charter'. ${ }^{48}$ Moreover, Eritrea's use of force was directed at areas which were 'all either within undisputed Ethiopian territory or within territory that was peacefully administered by Ethiopia'. ${ }^{49}$ Therefore, because there was no armed attack against Eritrea, its actions could not be justified as lawful self-defence under the UN Charter. ${ }^{50}$ In addition, the Claims Commission noted that Eritrea had failed to report its use of force against Ethiopia on

\footnotetext{
${ }^{44}$ ibid, para 10.

45 ibid, para 10.

46 ibid, para 10.

47 ibid, para 11.

48 ibid, paras 11-12.

49 ibid, para 15.

50 ibid, para 13.
} 
12 May 1998 to the Security Council as a measure taken in self-defence, in accordance to the procedural requirements embodied in Article 51 of the Charter. ${ }^{51}$

As regards Eritrea's third line of argument, that Ethiopia was the first to declare war on Eritrea, the Claims Commission held that Ethiopia only declared that it 'would not accept Eritrea's advances as a fait accompli and was determined to act in self-defense until the Eritrean forces withdrew or were compelled to leave the areas they had occupied'. ${ }^{2}$ According to the Claims Commission, 'the essence of a declaration of war is an explicit affirmation of the existence of a state of war between belligerents'; Ethiopia's resolution was not, as Eritrea had asserted, a declaration of war. ${ }^{53}$

The Claims Commission concluded that Eritrea's action to attack and forcibly take control over Badme and adjacent areas, which were at that time under the peaceful administration of Ethiopia, constituted a violation of Article 2(4) of the UN Charter. As a consequence, Eritrea was liable to compensate Ethiopia for the damages caused by this violation of international law. ${ }^{54}$

The outcome of the jus ad bellum ruling may well be welcomed or criticised, depending on one's reasoning and justification. The verdict could be, and has been, criticised due to the sensitivity and speciality of the subject matter involved. Gray, at first, gave the benefit of the doubt to the substantive jus ad bellum decision of the tribunal as follows: 'It may be that the Claims Commission's decision on the merits was a sustainable one. It may be that Eritrea was, in fact, responsible for violations of Article 2(4) in 1998.${ }^{55}$ However, she then questioned a) the mandate of the tribunal on jus ad bellum, b) the consistency of the award with the Boundary Commission decision 2002, and; c) the expertise of members of the Claims Commission and the role of an arbitral tribunal on matters of the law on the use of force. Each of these points is dealt with below. ${ }^{56}$

\footnotetext{
51 ibid, para 11.

52 ibid, para 17.

53 ibid, para 17.

54 ibid, para 16.

${ }^{55}$ Although the article also argues that the Commission 'did not give a satisfactory decision on the substantive law on the use of force', Gray (2006) p 721-722.

56 ibid.
} 
First, the mandate of the Claims Commission, as expressly provided for in Article 5(1) of the Algiers Agreement, includes deciding 'through binding arbitration all claims for loss, damage or injury by one Government against the other... related to the conflict --resulting from violations of international humanitarian law... or other violations of international law' ${ }^{57}$ As Gray observes, however, the same article appears to put some limitation on the mandate of the Claims Commission: 'The Commission shall not hear claims arising from the cost of military operations, preparing for military operations, or the use of force, except to the extent that such claims involve violations of international humanitarian law, ${ }^{58}$. Moreover, the Algiers Agreement envisages the establishment of a separate body with the duty of determining 'the causes of the conflict' ${ }^{59}$. Eritrea challenged the jurisdiction of the Claims Commission based upon these two different sentences of Article 5 (1) which forms the basis for Gray's criticism that the Commission may have exceeded its mandate.

The Claims Commission rejected Eritrea's argument, noting that a factual inquiry into 'origins' and 'misunderstandings' is not the same as a determination of the legal claim advanced by Ethiopia, which concerned whether Eritrea's actions in May and June 1998 constituted a violation of the jus ad bellum. As the Commission saw it, determining 'the origins of the conflict and the nature of any misunderstandings about the border, had they been made by an impartial body anticipated by Article 3, could have been helpful in promoting reconciliation and border delimitation, but they certainly would not have answered the question of the legality of Eritrea's resort to force.' The factual inquiries to be undertaken by the two bodies were not the same, and only the Commission was empowered to determine whether one of the states violated the jus ad bellum. ${ }^{60}$ Therefore, this rules out exceeding a mandate by the Claims commission over the issues of jus ad bellum.

However, as a second point, it might be asked whether arbitral tribunals should refrain from delivering a verdict on sensitive issues such as jus ad bellum, as a matter of judicial policy. One view may be that they should refrain from making bold decisions on issues of state responsibility for violation of Article 2(4) of the UN Charter in the interest of creating a nonconfrontational environment in which the parties could move to a speedy implementation of the decision 'without opening a new phase of proceedings concerning the calculation of due

\footnotetext{
${ }^{57}$ Article 5(1), Ethiopia/Eritrea Peace Agreement' (2000).

${ }^{58}$ ibid.

${ }^{59}$ Art 3, ibid.

${ }^{60} \mathrm{ibid}, 5$.
} 
compensation'. ${ }^{61}$ The contrary view may see the verdict at issue or other similar decisions as exemplary and a neutral application of the law on the use of force by legal experts for several reasons. The first is that all institutions of international law, including international arbitration, must contribute to upholding the fundamentals of the international legal order - the ban on the use of force is among them. When a state breaches the rules of the international legal order, this should be followed by the determination of a breach either to stop the breach itself or remedy the injury sustained as a result of the breach. Despite the potentially negative effect of this approach, the message of such a practice sent to the parties of a dispute or other third states would contribute towards deterring future violations of a fundamental norm of international law. ${ }^{62}$

This issue was raised by Judge Robinson in his separate opinion in Costa Rica v Nicaragua. ${ }^{63}$ In this case, Nicaragua occupied and deployed its troops in a territory which was under the administration of Costa Rica, but was also claimed by Nicaragua. Although the ICJ refrained from ruling on whether Nicaragua had used force in sending and deploying troops in the disputed territory, Judge Robinson provided a separate opinion on the issue, explaining that the hesitation on the part of international courts and tribunals to adjudicate on the issue of Article 2(4) in relation to disputed territories, is particularly problematic:

If indeed a line of jurisprudence is developing in which the Court abstains from ruling on the merits of claims of the use of force in a disputed territory, this course is to be regretted. Disputed territories are one of the most sensitive categories of international relations and particularly prone to provoking the use of force by states. A judicial practice of ruling on the merits of every claim by a state that another state has breached Article 2 (4) of the United Nations Charter would be entirely consistent with, and supportive of the system established after World War II for the maintenance of international peace and security and the Court's role in that system. ${ }^{64}$

Another reason might be to do with the weaknesses of the UN Security Council to discharge its duties on matters of the use of force. The determination of a violation of jus ad bellum is a

\footnotetext{
${ }^{61}$ Milano and Papanicolopulu (2011) 593.

${ }^{62}$ According to Mikanagi (2018) at 1034, finding a breach of the provisions of the UN Charter on the use of force and the peaceful settlement of disputes in relation to disputed territories contributes "to the "rule of law" in the international community, or the rule-based international order, by encouraging the settlement of disputes based on international law.' It also 'discourage[s] States from resorting to military measures to resolve international disputes in their favour and thus contribute[s] to the maintenance of international peace and security, which is the most important purpose of the UN.

${ }^{63}$ Costa Rica v Nicaragua (2015).

${ }^{64}$ Costa Rica v Nicaragua (2015) (Sep Op Judge Robinson) paras 43, 58-59; see also separate opinion of Judge Simma in Iran $v$ United States of America (2003), para 327-328.:

[It is] regrettable that the Court has not mustered the courage of restating, and thus re-confirming, more fully fundamental principles of the law of the United Nations as well as customary international law (principles that in my view are of the nature of jus cogens) on the use of force, or rather the prohibition on armed force, in a context and at a time when such a reconfirmation is called for with the greatest urgency.
} 
highly politicised business and the Council is often reluctant to determine a wrong-doing relating to this subject. Therefore, the ICJ and other international tribunals should undertake to fill this gap when they are mandated by states to resolve a dispute such as the one involving Eritrea and Ethiopia. Finally, such verdicts contribute to enhancing our understanding of the laws and their application, in this case on the convergence or supplementarity of jus ad bellum and the law of territory.

Second, the argument that 'the Claims Commission in the jus ad bellum case paid very little respect to the Delimitation Decision of the Boundary Commission' might appear plausible at the first glance from consistency perspective of resolving a dispute. ${ }^{65}$ However, as this article shows, the norms prohibiting the use of force and the laws requiring respect for sovereignty and territorial integrity serve distinct functions; 'they reflect overlapping, but not identical, concerns'. ${ }^{66}$ Most importantly, the mandates of the two Commissions were different, one was charged with delimiting the boundary between the two countries while the other with claims of loss or damage arising from violations of international law. Relying on the notion of consistency without due regard to questions of justice and jus cogens violations would have been a very serious mistake and miscarriage of international justice.

Third, and finally, the argument that the arbitrators' 'main area of expertise' is not in the 'field of jus ad bellum ${ }^{, 67}$ does not appear to be convincing given that they are all highly recognised scholars and practitioners of public international law with the capacity, skills, and experience in determining legal claims that emanate from violations of international law, including matters involving the use of force. ${ }^{68}$ As a result, they have dealt not only with jus ad bellum but also with jus in bello violations. If we accept the argument on expertise, should we also question and probe whether or not members of the Claims Commission have expertise in international humanitarian law and the law of territory? Not really. What the arbitrators have done is to apply well-established rules of international law to the facts that are well-known and, to a large extent,

\footnotetext{
${ }^{65}$ Gray (2016) 707-710.

${ }^{66}$ Costa Rica v Nicaragua (2015) (Sep Op Judge Robinson) para 39.

${ }^{67}$ Gray (2016) 707.

${ }^{68}$ Hans van Houtte, the President of the Claims Commission, is Chair holder in public international law at Leuven University with strong practice in arbitration including as President of the Iran-US Claims Tribunal; Judge George H Aldrich, Professor of international (humanitarian) law at Leiden University is also experienced on matters of international law including as a member of the International Law Commission; John R Crook is a senior figure in the field of public international law including acting as president of the American Society of International law, Judge on NATO's Administrative Tribunal and advisor to the United States Government; James CN Paul was Professor of Law Emeritus and Dean of Rutgers School of Law-Newark in the United States with several books publications on public international law; and Lucy Reed, a renowned public international lawyer.
} 
uncontested by Eritrea. As examined in the following section, the Claims Commission has looked at the basic question: Whether the use of force can be deployed as a means of regaining territorial rights under international law.

\subsection{Jus ad bellum rules are applicable to territorial disputes}

The Eritrea-Ethiopia Claims Commission affirmed that the rules of international law on the use of force make no exception in respect of disputed territories. According to the Commission, recognising such an exception would significantly weaken the fundamental rule of international law prohibiting the use of force. ${ }^{69}$ This finding was, in fact, re-stated in the Guyana/Suriname case of $2007 .^{70}$ In this case, Surinamese naval vessels boats had threatened Guyana's concessionaires operating an oil rig in the disputed areas to 'leave the area in 12 hours' or 'the consequences will be [theirs]'. ${ }^{71}$ Suriname believed it had a valid claim to the area in question and, thus, that it had the right to forcibly expel the operators of the rig as part of legitimate law enforcement measures. ${ }^{72}$ The arbitral tribunal found that the action by Surinamese Navy was more akin to a threat of force than a law enforcement activity. ${ }^{73}$ While this is a law of the sea case, it is remarkable in that a threat of force by Suriname within the maritime area claimed by Suriname, also represented a breach of 2(4) of the UN Charter, which the Guyana/Suriname tribunal found remains applicable in the context of both territorial and maritime boundary disputes. ${ }^{74}$

That the prohibition of the use of force applies to disputed territories is also supported by state practice, as shown in the following indicative examples. The UN Security Council Resolutions 242 (1967) and 298 (1971), adopted by majority vote in response to the Israeli-Palestinian conflict, stressed the inadmissibility of acquiring territory by force whilst calling for the '[w]ithdrawal of Israel armed forces from territories occupied in the recent conflict' and ' $\mathrm{t}$ ] ermination of all claims or states of belligerency'. ${ }^{75}$ Moreover, the majority of the members of the Security Council strongly condemned Argentina's 1982 military invasion of the Falkland Islands, to recover them from the United Kingdom, whose territorial title over the Falklands

\footnotetext{
${ }^{69}$ Eritrea-Ethiopia Claims Commission, Partial Award, Jus ad Bellum: Ethiopia's Claims 1-8 (19 December 2005) para 10.

${ }^{70}$ Guyana/Suriname (Award) (2007).

71 ibid, paras 433, 445.

72 ibid, para 433.

73 ibid, paras 433,445 .

74 ibid, paras 423, 483-484.

${ }^{75}$ Security Council Resolutions 242 (1967) (22 November 1967) and 298 (1971) (25 September 1971).
} 
Argentina rejected. ${ }^{76}$ In relation to the military conflict in the former Yugoslavia, the UN Security Council also re-stated the inadmissibility of the alteration of international boundaries through the use of force. ${ }^{77}$

In connection to the armed conflict between Eritrea and Ethiopia along their disputed boundary, the Security Council passed Resolution 1177 (1998) expressing its 'grave concern at the conflict' and stressing that 'the use of armed force was not acceptable as a means of addressing territorial disputes or changing circumstances on the ground' ${ }^{78}$ In 1999 , after the conflict escalated to a full-scale war, the Security Council, in Resolution 1227 (1999), condemned the recourse to force by Ethiopia and Eritrea and demanded an immediate end to the hostilities. ${ }^{79}$ Therefore, it is clear that the use of force as a means of acquiring territory and settling international disputes, including disputes over territory, is contrary to international law. ${ }^{80}$

The Declaration on Friendly Relations emphasises that point in stipulating that:

Every State has the duty to refrain from the threat or use of force to violate the existing international boundaries of another State or as a means of solving international disputes, including territorial disputes and problems concerning frontiers of States [emphasis added]. ${ }^{81}$

The threat or use of force by one state against another would not escape the scope of Article 2(4) of the UN Charter simply because they take place in, or are directed at, a disputed territory. As the Eritrea-Ethiopia Claims Commission and the Guyana/Suriname tribunal respectively confirmed, the legal status of the territory in question (delimited or undelimited, demarcated or not clearly demarcated, disputed or not subject to a dispute) does not affect the characterisation of a certain conduct as a threat or use of force in the sense of Article 2(4) of the UN Charter. ${ }^{82}$

\footnotetext{
${ }^{76}$ Security Council Official Records S/PV 2345 (1 April 1982); Security Council Official Records S/PV 2346 (2 April 1982); Security Council Resolution 502 (3 April 1982) noted that the 'invasion on 1982 by armed forces of Argentina' and demanded Argentina to withdraw its forces from the Falklands; Security Council Resolution 505 (26 May 1982), noting 'with the deepest concern that the situation in the region of the Falkland Islands (Islas Malvinas) has seriously deteriorated'.

${ }^{77}$ Security Council Resolutions 752 (15 May 1992) and 757 (30 May 1992), 'no territorial gains or changes brought about by violence are acceptable'.

${ }^{78}$ Security Council Resolution 1177 (26 June 1998).

${ }^{79}$ Security Council Resolution 1227 (10 February 1999).

${ }^{80}$ Crawford (2006) 131-132.

81 'Declaration on Principles of International Law concerning Friendly Relations and Co-operation among States in accordance with the Charter of the United Nations' 2625 (XXV) (24 October 1970).

${ }^{82}$ Eritrea-Ethiopia Claims Commission, Partial Award, Jus ad Bellum: Ethiopia's Claims 1-8 (19 December 2005) para 10; Guyana v Suriname (2007) para 423.
} 


\subsection{The administrative status quo is legally protected under jus ad bellum}

Another important aspect of the Eritrea-Ethiopia jus ad bellum award concerns the relationship between the prohibition on the use of force and the principles of sovereignty and territorial integrity. Article 2(4) of the UN Charter provides that member states shall refrain from the threat or use of force 'against the territorial integrity... of any State' ${ }^{83}$ As noted above, the principles of sovereignty and territorial integrity protect the legitimate holder of sovereignty title over a given territory from adverse or belligerent occupation, unilateral incursions, and violations of its land borders by other states. However, when that title of sovereignty is rejected by another state, or when the legal status and location of the border itself is unclear, the protection afforded by this principle is truly meaningful only after the dispute has been settled and the situation is characterised ex-post facto as an unlawful occupation or as a breach of that state's territorial integrity in contravention of international law. ${ }^{84}$ If the essential basis for the protection of sovereignty, namely a title to territory, remains obscure and will not become clear until the dispute resolution process is completed, then the preservation of the factual situation on the ground becomes crucially important.

The Eritrea-Ethiopia jus ad bellum case shows that in the context of a disputed territory, where two or more states oppose each other's sovereignty claim, and where there is no clear answer as to which state holds title over that territory, what the law protects, pending the settlement of the dispute, is not so much the territorial integrity of the holder of a valid title in the disputed territory (which can be either of the two claimants), but rather the existing administrative status quo on the ground. Indeed, in 1998 Eritrea directed its armed attack at Badme and the surrounding area which were administered at the time by Ethiopia. In 2002, the Boundary Commission delimited the boundary, meaning that Badme subsequently fell within Eritrean territory. ${ }^{85}$ The Eritrea-Ethiopia Claims Commission found that even if Eritrea was correct in May 1998 that it held a valid title of sovereignty over Badme, this could not condone the illegality of its resort to force against Ethiopia (i.e. the administering state). ${ }^{86}$

\footnotetext{
${ }^{83}$ The ICJ has repeatedly emphasised that the principle of territorial integrity is an important feature of the international legal order, see Kosovo Advisory Opinion (2010) para 80; Costa Rica v Nicaragua (Provisional Measures) (Order of 16 July 2013) paras 13-14.

${ }^{84}$ Milano and Papanicolopulu (2011) 589.

${ }^{85}$ Eritrea-Ethiopia Boundary Commission, Decision Regarding Delimitation of the Border (13 April 2002); The Boundary Commission was composed of Professor Sir Elihu Lauterpacht (President), Prince Bola Adesumbo Ajibola, Professor Michael Reisman, Judge Stephen Schwebel, and Sir Arthur Watts.

${ }^{86}$ Eritrea-Ethiopia Claims Commission, Partial Award, Jus ad Bellum: Ethiopia's Claims 1-8 (19 December 2005) para 10.
} 
Seen from this angle, the factual reality on the ground forms the relevant baseline against which to test the application of jus ad bellum where the use of force is engaged in the context of a territorial dispute. The relevant exercise in any given situation is to ascertain which of the two claimants has crossed this baseline, in other words, which party was the first to disturb the existing territorial status quo on the ground, through the use of force.

That the factual reality on the ground is immune to unilateral modifications by force is also supported by relevant state practice. The Goan incident between India and Portugal is a good example in that regard. Armed disputes erupted between India and Portugal in 1961, over the disputed territory of Goa. Portugal had held Goa as an overseas territory since it was first acquired in 1510, however, following India's independence in 1947, India had been placing increasing pressure upon the Portuguese to release their claim over the country. IndoPortuguese tensions increased from the mid-1950s onwards, and in November 1961 shots were fired at Indian fishing vessels passing near the Goan border, killing a passenger onboard. These tensions culminated in December 1961, when Indian troops were sent over the border into Goa, in order to seize control of the state. In the period leading up to the conflict, the UN urged both sides to negotiate peacefully and to avoid outright warfare, with the UK government also calling for restraint. The December dispute lasted less than 24 hours, with the significantly outnumbered Portuguese troops having withdrawn by December $19^{\text {th }}$. Third states including the United States and the United Kingdom outwardly condemned India's actions, and the international press also criticised India's handling of the situation, with the British Times indicating that Indian authorities had exaggerated the potential for 'anarchy and chaos ${ }^{97}$ in order to seize control. Conversely, India denied any breach of the U.N. Charter on the basis that Portugal had itself breached the Charter in its 'repeat provocations', hence India's actions were justified $^{88}$.

The Doklam incident, which took place in summer 2017 and saw India and China engaged in a 73-day stand-off along their shared border, is a similar example. The two countries have been involved in an unresolved dispute over the border since the Sino-Indian War of 1962, where repeat skirmishes in Aksai Chin culminated in full armed conflict. In 1967 military conflict broke out again, with attacks on both sides at Nathu La in eastern-Sikkim, and in October 1975

\footnotetext{
${ }^{87}$ Keesing's Contemporary Archives, 'Indian Occupation of Portuguese Territories in India', (Volume 8, March 1962 ), 10. 88 ibid, 9.
} 
four Indian soldiers were shot by Chinese military on the 'McMahon Line' between Tibet and Assam $^{89}$. The 2017 incident was one of the most severe escalations over the past decade, with India reacting against China's attempts to build a border road through the disputed area of Doklam, which sits between China, the Indian State of Sikkim and Bhutan. The Bhutanese also rejected the road, claiming that the construction breached existing agreements between China and Bhutan.

Third countries voiced concerns over the territory dispute; Australia, the United Kingdom and the United States all urged China and India to engage in peaceful negotiation, and the Indian Express reported Japanese Ambassador Hiramatsu's comments that the parties involved should 'not resort to unilateral attempts to change the status quo by force but resolve the dispute in a peaceful manner ${ }^{90}$ Although the face-off came to an end on 28 August 2017, tensions continue to simmer and each side persist in placing troops along the border. The vigorous reaction of third countries to the Doklam incident, however, supports the notion that the factual status quo continues to be advocated and protected in international law when it comes to disputed territories.

\subsection{Force cannot be used to reclaim territory}

Another important lesson that can be drawn from the Eritrea-Ethiopia jus ad bellum award is that force cannot be used retroactively to correct situations of unlawful occupation of a territory, on grounds of self-defence. In essence, a state cannot legitimately invoke a right of self-defence to forcibly take control over a disputed area which is under the de facto control and administration of another state, even if it aimed at correcting a 'past injustice'. 91

For an exercise of self-defence to be regarded as legitimate, three key requirements must be met: a) self-defence can only be taken in response to 'an armed attack' ${ }^{92}$; b) it must be directed against the state responsible for the attack (the state to whom the armed attack can be attributed) $;{ }^{93}$ and c) any act of self-defence must be carried out within the limits of necessity

\footnotetext{
${ }^{89}$ Keesing's Contemporary Archives, 'India-China: Indian Soldiers Killed in Border Incident' (30 January 1976).

${ }^{90}$ Roy (2017).

${ }^{91}$ Arend (1984) 102.

${ }^{92}$ An 'armed attack' is a type of aggression, as provided by UNGA Res 3314 (XXIX) (14 December 1974) on the Definition of Aggression.

${ }^{93}$ Armed Activities on the Territory of the Congo (2005] para 146.
} 
and proportionality. ${ }^{94}$ Article 51 of the UN Charter sets out a further procedural requirement to report any measures taken in self-defence to the Security Council, along with the closely associated obligation to cease forcible actions when the Security Council has 'taken measures necessary to maintain international peace and security'. ${ }^{95}$

In the case of Eritrea and Ethiopia, the Claims Commission, after carefully examining the factual evidence presented before it, found that the conditions giving rise to the right of selfdefence were not met. The Commission ultimately concluded that 'localised border encounters between small infantry units, even those involving the loss of life, do not constitute an armed attack' for the purposes of the UN Charter. ${ }^{96}$ Hence, Eritrea had failed to establish that the minor skirmishes which had taken place between Eritrean and Ethiopian forces leading up to the Badme incident were sufficient to justify armed retaliation on Eritrea's part, on the grounds of self-defence; their actions were thus in violation of the UN Charter and constituted a breach of international law. Eritrea was also precluded from invoking the right to self-defence because it failed to comply with the requirement of reporting to the Security Council as required by Art 51 of the Charter. ${ }^{97}$

Moreover, the requirement that forcible action in self-defence only be exercised in response to an armed attack implies a condition of immediacy, namely that the action cannot be taken long after the armed attack has occurred. ${ }^{98}$ The armed conflict between Argentina and Britain over the Falkland Islands is a useful reflection of this condition. On 2 April 1982, Argentina invaded and occupied the Falkland Islands which had been under Britain's control and administration since 1832. Argentina considered that because Britain had seized the territory by force in 1833 , and given the lack of progress in diplomatic negotiations, it was justified in reclaiming the islands despite the intervening time. ${ }^{99}$ The British government swiftly dispatched its Royal Navy in the area and appealed to the Security Council to demand the immediate withdrawal of

\footnotetext{
${ }^{94}$ Military and Paramilitary Activities in and against Nicaragua (1986) paras 194, 237; Legality of the Threat or Use of Nuclear Weapons (Advisory Opinion) (1996) para 41.

${ }^{95}$ Art 51, UN Charter; In the Nicaragua case, the Court implied that when the use of force is governed by the UN Charter, failure to adhere to the reporting duty under the Charter carries irrevocable consequences for the invocation of the right of self-defence, Military and Paramilitary Activities in and against Nicaragua (1986) para 199.

${ }^{96}$ Eritrea-Ethiopia Claims Commission, Partial Award, Jus ad Bellum: Ethiopia's Claims 1-8 (19 December 2005) para 11.

97 ibid.

98 Dinstein (2001) 165-167.

${ }^{99}$ Prior to the invasion, General Galtieri, leader of the Argentine military government told to President Reagan of the United States of America that the British had failed to relinquish sovereignty in 149 years and that 'time had run out', see 'Reagan, In a Phone Call, Tried to Deter Invasion' (New York Times, 3 April 1982) cited in F Hassan, 'The Sovereignty Dispute over the Falkland Islands' (1982) 23(1) Virginia Journal of International Law 54, 59; Security Council Official Records S/PV 2346 (2 April 1982) para 12.
} 
Argentine forces. The Security Council, by Resolution 502 of 3 April 1982, demanded that both governments immediately cease all hostilities and that Argentina immediately withdraw all its forces from the Falkland Islands. ${ }^{100}$ The Resolution recognised the existence of a 'breach of the peace' as a result of the Argentine invasion and placed the onus on Argentina to withdraw, whilst calling upon both sides to pursue the peaceful settlement of this dispute. The British forces were able to dislodge Argentine forces from the Islands after 72 days of Argentine occupation. The two countries reached a de facto ceasefire in June 1982. The Falklands crisis of 1982 revealed the belief of the majority of the members of the Security Council that the use of force by Argentina to gain control over the Islands constituted an armed attack against the United Kingdom. ${ }^{101}$ The latter, being the attacked State, acted legitimately in self-defence to protect its possession of the Islands. ${ }^{102}$

It should be noted that whilst forcible action in self-defence cannot be taken long after an armed attack on the disputed territory, delayed forcible action may still be legitimate if the lapse of time is warranted by the circumstances. For example, adequate time is usually required as the attacked State deliberates on or plans its next move, or if an attempt is first made to resolve the matter amicably via diplomatic means prior to resorting to self-defence but is persistently refuted by the latter. ${ }^{103}$ However, as it was noted above, forcible action cannot be used to correct retroactively situations of perceived past injustice on grounds of self- defence.

The immediacy requirement and the existence of a territorial status quo to test the applicability of Article 2(4) have crucial implications for a dispossessed State's right to use forcible means to retake its territory. There are only two situations where a State which has lost a territory can forcibly reclaim it. The first situation is where there has been a UN Security Council's authorisation to use force. This is not done pursuant to the right of self-defence but instead the Security Council's power to maintain or restore international peace and security under Chapter VII of the UN Charter. One example is Security Council Resolution 678 which authorised UN Member States to use 'all necessary means' to uphold and implement resolution 660 to drive Iraq out of Kuwait following its invasion in $1990 .{ }^{104}$

\footnotetext{
${ }^{100}$ UN Security Council Res 502/1982 reproduced in (1982) 21 International Legal Materials 679.

101 As evidenced by the widespread support (10 yes, 1 no and 4 abstentions) for Security Council Resolution 502/1982 demanding the 'immediate withdrawal of all Argentine forces from the Falkland Islands (Islas Malvinas)'.

${ }^{102}$ Greenwood (2012) 108; Waibel (2012) 1116.

103 Y Dinstein, War, Aggression and Self-Defence (3rd edn, Cambridge University Press 2001) 212-213.

${ }^{104}$ UN Security Council Resolution 678 (29 November 1990); for other examples and analyses of the UN Security Council authorisation of the use of force, including Resolution 678, see, among others, B Weston, 'Security Council Resolution 678 and Persian Gulf Decision Making: Precarious Legitimacy' (1991) 85 American Journal of International Law 516, 517; N
} 
The second situation is where a State is attacked and uses force in self-defence, pursuant to the requirements of Article 51 of the UN Charter, to protect the territory it administers. International law, as was seen above, protects the factual reality in existence on the ground, included in a disputed territory, when it comes to the use of military force. The immediacy requirement is of crucial importance here: if State A attacks neighbouring State B and occupies part of State B's territory and State B does not respond within a reasonable period of time; it loses the ability to rely on self-defence to retake its territory by force. The right to use force in self-defence cannot be reactivated at a later stage. Thus, unless the attacked State makes a forcible response which conforms to the requirements of self-defence within a reasonable time, it may be confronted with the newly established territorial status quo which it will be bound to respect ${ }^{105}$ as far as waging war to change the situation is concerned.

The Russian swift take-over of Crimea presents a good case-study to test the extent and scope of the territorial status quo in its interaction with the right of self-defence. On 28 February 2014, Russian armed forces moved out of their naval base on the Black Sea and took over Crimea, triggering a crisis with Ukraine. ${ }^{106}$ On 3 March, at the UN Security Council, Ukraine claimed 16,000 Russian troops had entered Crimea. ${ }^{107}$ Russia has put forward complex arguments under international law to attempt to justify its military action in Crimea and Eastern Ukraine, none of which is adequate to avoid the charge of aggression. ${ }^{108}$ The Ukrainian acting Prime Minister, called upon Russia 'to immediately withdraw its troops, return to the place of deployment and stop provoking civil and military confrontation in Ukraine' and mobilized Ukrainian troops to counter Russian troops. ${ }^{109}$ However, no counter-action was taken involving military force against Russian troops. On 15 March 2014, pro-Russian Crimean declared Crimea independent and on 18 March 2014, Russian President Vladimir Putin announced that Russia had annexed Crimea; Ukrainian troops withdrew from the peninsula one week later. ${ }^{110}$

Blokker, 'Is the Authorisation Authorised? Powers and practice of the UN Security Council to authorize the use of force by 'coalitions of the able and willing' (2000) 11 European Journal of International Law 541; N Blokker, 'Outsourcing the Use of Force: Towards More Security Council Control of Authorized Operations?' in M Weller (ed.), The Oxford Handbook of the Use of Force in International Law (Oxford University Press 2015), 202(226.

105 see Yiallourides, Gehring and Gauci (2018) 81-82.

106 O'Connell (2018) 855.

${ }^{107}$ O’Connell (2018) 855.

108 O'Connell (2018) 855; see also Daniel Wisehart, 'The Crisis in Ukraine and the Prohibition of the Use of Force: A Legal Basis for Russia's Intervention?' (EJIL-talk!, 4 March 2014) <https://www.ejiltalk.org/the-crisis-in-ukraine-and-theprohibition-of-the-use-of-force-a-legal-basis-for-russias-intervention/>.

${ }^{109}$ Alison Smale and Steven Erlanger, 'Ukraine Mobilizes Reserve Troops, Threatening War' (New York Times, 1 March 2014) 〈https://www.nytimes.com/2014/03/02/world/europe/ukraine.html>

${ }^{110}$ O’Connell (2018) $855-856$. 
Russian has, therefore, effectively occupied part of Ukraine's territory by force and has established its administration in there. A new factual reality has come into existence. This new factual reality on the ground forms the new administrative status quo. Ukraine did not militarily react at the time of the Russian attack and, therefore, may well have lost the ability to rely on self-defence at a later stage. Ukraine, the dispossessed state, may not reactively take up arms and attack the area which Russian, the administering state, currently occupies, on the basis of self-defence. If Ukraine attempts to forcibly take-over Crimea, then Russia, as the current administrator of the occupied area, may well defend the territory by invoking self-defence against Ukraine, provided that the requirements of self-defence under Article 51 of the UN Charter are satisfied. How Russia established itself on the occupied territory and, how the new status quo came into existence does not affect its right to defend the territory in question against future attacks. In all, in view of the requirement that forcible action in self-defence must be 'temporally interwoven' with the armed incident triggering it, if Ukraine somehow obtained sufficient military power to try to take Crimea back from Russia by force, it would not be legally permitted to do so considering the significant time that has elapsed since the Russian invasion and occupation of Crimea. ${ }^{111}$

However, Ukraine and third states, can still take countermeasures in response to Russia's internationally wrongful act - the annexation of territory by force. ${ }^{112}$ Such countermeasures will be lawful provided that they comply with the substantive and procedural requirements laid down in the International Law Commission Draft Articles on Responsibility of States for Internationally Wrongful Acts. It is instructive that among the examples of continuing wrongful acts given by the International Law Commission is that of the 'unlawful occupation of part of the territory of another State or stationing armed forces in another State without its consent'. ${ }^{113}$ So long as Russia's annexation persists, the internationally wrongful act will be continuing, and Ukraine, as well as third states, will be able to take or continue to take countermeasures against Russia. ${ }^{114}$ Hence, while Ukraine cannot resort to forcible means to reverse the situation and reclaim its territory, it can take lawful countermeasures or other lawful and peaceful action against Russia to compel the latter to cease its wrongful act. This example

\footnotetext{
111 see Dinstein (2001) 219.

112 Paddeu (2015); Milano (2004) 509; BBC, 'Ukraine Crisis: Russia and Sanctions' (19 December 2014) <http://www.bbc.co.uk/news/world-europe-26672800>; 'EU Sanctions Against Russia over Ukraine Crisis' <https://europa.eu/newsroom/highlights/special-coverage/eu-sanctions-against-russia-over- ukraine-crisis_en>.

${ }^{113}$ ILC Articles on State Responsibility 31, 60; see also Art 37 (point 4), ILC Articles on State Responsibility.

${ }^{114}$ For an account, see Tams (2005).
} 
illustrates that, while international law protects the existing administrative status quo on the ground, it does not necessarily recognise this status quo as lawful; rather it recognises that an internationally wrongful act has been committed and empowers the dispossessed State to take non-forcible measures against the aggressor State in response. This is not withstanding the right of the people to external self-determination and a collective response and decision by the UNSC for example, which can include armed resistance or the authorisation of full-scale military force against occupiers, which are not within the scope of this article.

Clearly, this case-study is relevant to the Eritrea-Ethiopia jus ad bellum case as Eritrea tried to justify its use of military force inter alia based upon the prior control of its territory by Ethiopia, which was rightly rejected by the Claims Commission. However, the Crimea and EritreaEthiopia cases have major differences, including the absence of prior aggression by Ethiopia against Eritrea, when the latter invaded Ethiopia in 1998. For this reason, therefore, the lapse of time argument made in relation to territorial occupation and self-defence will have to be applied with caution on a case-by-case basis, taking into consideration all relevant circumstances and applicable international laws.

\subsection{A new era of peace and cooperation on the horizon}

Almost twenty years after the end of the war, the political relations of Eritrea and Ethiopia have been characterised by a perpetual 'no war, no peace' stalemate with serious economic and security implications on both sides, and the Horn of Africa at large. ${ }^{115}$ However, after a change of leadership in Ethiopia in June 2018, the Ethiopian ruling party and the Government led by the newly elected Prime Minister took a fresh and unconditional peace offer to Eritrea, which was swiftly welcomed by Eritrea. ${ }^{116}$ In a fairly short period of time, the two countries have begun to normalise their relations - including opening up their respective borders to their citizens, commencing inter-state flights to, and from, both capitals and undertaking preparations for the use of Eritrean ports by Ethiopia, and regulating trading relations of the two countries.

At the time of writing, the leaders of the two countries signed a peace and friendship agreement in Jeddah in the presence of UN Secretary-General António Guterres and King Salman of Saudi

\footnotetext{
${ }^{115}$ For a discussion, see Woldemariam (2018) 407-427.

116 Gebrekidan (2018).
} 
Arabia. ${ }^{117}$ According to Addis Standard, an Ethiopian English newspaper, the agreement considers 'the close bonds of geography, history, culture and religion between the two countries and their peoples', the need for 'Respecting each other's independence, sovereignty and territorial integrity' and affirming 'their commitment to the principles and purposes of the Charter of the United Nations'. ${ }^{118}$ According to the same source, the two leaders agreed to, inter alia, end 'the state of war' and start 'a new era of peace, friendship and comprehensive cooperation...on the basis of complementarity and synergy'. This new era includes: a) full implementation of 'the Eritrea-Ethiopia Boundary Commission's decision; b) 'comprehensive cooperation' on matters of political, security, defence, economic and trade; c) development of 'investment projects' and; d) promotion of 'regional and global peace, security and cooperation'. 119

These are very ambitious commitments, the details of which are not yet clear. While such developments should be welcomed, considering the contributions and reflections of others to this same volume on the many dimensions of the Eritrea-Ethiopia case and the way forward for the two east African neighbours, the final section of this article outlines the main lessons that ought to be learnt from the Claims Commission's jus ad bellum award in relation to disputes over territory ${ }^{120}$.

\footnotetext{
${ }_{117}$ Cornwell (2018).

118 Agreement on Peace, Friendship and Comprehensive Cooperation Between the Federal Democratic Republic of Ethiopia and the State of Eritrea (18 September 2018) available at <http://addisstandard.com/full-text-of-the-ethio-eritrea-agreementsigned-in-jeddah/>.

Article One

The state of war between the two countries has ended and a new era of peace, friendship and comprehensive cooperation has started.

Article Two

The two countries will promote comprehensive cooperation in the political, security, defense, economic, trade, investment, cultural and social fields on the basis of complementarity and synergy.

Article Three

The two countries will develop Joint Investment Projects, including the establishment of Joint Special Economic Zones.

Article Four

The two countries will implement the Eritrea-Ethiopia Boundary Commission decision.

Article Five

The two countries will promote regional and global peace, security and cooperation.

Article Six

The two countries will combat terrorism as well as trafficking in people, arms and drugs in accordance with international covenants and conventions.

Article Seven

The two countries will establish a High-Level Joint Committee, as well as Sub-committees as required, to guide and 119 ibid. oversee the implementation of this Agreement.

${ }^{120}$ According to media reports, Ethiopia has started withdrawing its troops from Badme, 'Ethiopia Withdraws Troops from Contested Town (BBC World Service, 18 December 2018) <https://www.bbc.co.uk/programmes/w172w23x1zrpc04>
} 


\section{Lessons and some Conclusions}

First, rightly or wrongly, international law prioritises peace and border stability over justice. Where borders are unclear or the status of a territory is disputed, the law on the use of force takes its lead primarily from the factual reality on the ground. Although Ethiopia was administering territory belonging, in effect, to Eritrea, the Claims Commission made clear that Eritrea's forcible attempt to overturn Ethiopia's administration or occupation was an unlawful use of force in violation of Article 2(4) of the UN Charter. Neither could such forcible attempt been accepted as self-defence in the absence of an armed attack against Eritrea. Force cannot be used to modify a border, however disputed, or to change the status quo on the ground. The administering state is legally permitted to use force to defend its administration over the disputed territory through an exercise of its right of self-defence.

Secondly, wars between countries can have various causes ranging from socio-economic and ideological matters to that of territorial claims. The Eritrea-Ethiopia case is clearly a good example of dealing with a devastating armed conflict caused by various factors but later painted in the guise of a boundary war. The latter may well have been used as a pretext for waging war despite being caused by other national, regional and international political rivalry. Whatever the causes of the war might have been, the resort to force as a means of advancing a territorial claim is outlawed by international law. The analysis contained in this piece affirms this bold conclusion from which the two Horn of Africa countries at issue, and others in the international community, should draw important lessons.

Thirdly, there is no question that the UN Security Council, or other regional organisations, are often charged with dealing with or facilitating the resolution of use of force related disputes and situations. Given the political and practical limitations of such bodies in effectively and consistently responding to matters of the use of force and territorial disputes including claims of loss or damage arising from such events, it is important to recognise the role of international adjudicating bodies, such as arbitral tribunals, in applying the law, determining international responsibility and clarifying the laws under consideration. This should also be commended to promote and uphold international peace, stability and justice.

Finally, the aforementioned key points and the emerging positive relations between Ethiopia and Eritrea, which appear to go beyond resolving the border question, demonstrate that border 
wars are tremendously easy to start (it only takes a single border incident) but very hard to end and their implications are lasting and far-reaching on all sides. The two countries, and others, ought to learn hard lessons from the Eritrea-Ethiopia case and totally avoid military solutions to any territorial claims, interests or ambitions they might have, other than peacefully seeking beneficial cooperation in a spirit of understanding, good neighbourliness and good faith.

\section{Short bio of authors}

Dr Constantinos Yiallourides is the Arthur Watts Research Fellow on the International Law of Territorial Disputes at the British Institute of International and Comparative Law (BIICL) where he leads the Watts programme of research and events on maritime and territorial disputes.

Professor Zeray Yihdego holds a chair in Public International law, and is Co-director of the Centre for Constitutional and Public International Law at the University of Aberdeen.

With thanks to Olivia Kirkbride, Research Volunteer in Public International Law, British Institute of International and Comparative Law (BIICL). Any errors or omissions remain the authors' own. 


\section{References}

'Declaration on Principles of International Law Concerning Friendly Relations and Cooperation Among States in Accordance with the Charter of the United Nations', UN General Assembly Resolution (UNGA) 2625 (XXV) (24 October 1970) reprinted in (1970) 9 International Legal Materials 1292 [Declaration on Friendly Relations].

International Law Commission Draft Articles on Responsibility of States for Internationally Wrongful Acts, with commentaries (2001) 2(2) Yearbook of the International Law Commission 31, 60 [ILC Draft Articles on State Responsibility]

'Peace Agreement' (Eritrea-Ethiopia) (signed and entered into force 12 December 2000) https://www.files.ethz.ch/isn/125337/1392_Algiers\%20Agreement.pdf [the 'Algiers Agreement'].

Accordance with International Law of the Unilateral Declaration of Independence in Respect of Kosovo (Advisory Opinion) [2010] ICJ Rep 403 [Kosovo Advisory Opinion].

Armed Activities on the Territory of the Congo (Congo v Uganda) (Judgment) [2005] ICJ Rep 168.

Certain Activities carried out by Nicaragua in the Border Area (Costa Rica v Nicaragua); Construction of a Road in Costa Rica along the San Juan River (Nicaragua v Costa Rica) (Order of 16 July 2013) (Provisional Measures) [2013] ICJ Rep 275.

Certain Activities Carried Out by Nicaragua in the Border Area (Costa Rica v Nicaragua); Construction of a Road in Costa Rica along the San Juan River (Nicaragua v Costa Rica) (Judgment) [2015] ICJ Rep 665.

Corfu Channel (United Kingdom/Albania) (Judgment) (Merits) [1949] ICJ Rep 4.

Eritrea-Ethiopia Boundary Commission, Decision Regarding Delimitation of the Border (13 April 2002) XXV Reports of International Arbitral Awards 83-195.

Eritrea-Ethiopia Claims Commission, Partial Award, Jus ad Bellum: Ethiopia's Claims 1-8 (19 December 2005) XXVI Reports of International Arbitral Awards 457-469.

Guyana/Suriname (Annex VII Tribunal) (Award) (2007) 47 International Law Reports 166.

Island of Palmas Case (or Miangas) (United States $v$ The Netherlands) (Award) (1928) II Reports of International Arbitral Awards 829.

Legality of the Threat or Use of Nuclear Weapons (Advisory Opinion) [1996] ICJ Rep 226.

Military and Paramilitary Activities in and against Nicaragua (Nicaragua $v$ United States of America) (Judgment) [1986] ICJ Rep 14.

North Atlantic Coast Fisheries Case (Great Britain/United States of America) (Award) (1910) 4 American Journal of International Law 948.

Oil Platforms (Iran v United States of America) (Judgment) [2003] ICJ Rep 161.

UN Security Council, 'Special Report of the Secretary-General on Ethiopia and Eritrea' (15 December 2016) S/2006/992.

Arend A, 'The Obligation to Pursue Peaceful Settlement of International Disputes During Hostilities' (1984) 24(1) Virginia Journal of International Law 97.

Bernárdez S, 'Territorial Sovereignty' in Encyclopedia of Public International Law Vol 10 (North Holland 1987) 487-94.

Besson S, 'Sovereignty' in Max Planck Encyclopedia of Public International Law (online edition, updated 2011).

Blay S, 'Territorial Integrity and Political Independence' in Max Planck Encyclopedia of Public International Law (online edition, updated 2010). 
Blokker N, 'Is the Authorisation Authorised? Powers and practice of the UN Security Council to authorize the use of force by 'coalitions of the able and willing' (2000) 11 European Journal of International Law 541.

Blokker N, 'Outsourcing the Use of Force: Towards More Security Council Control of Authorized Operations?' in Weller M (ed) The Oxford Handbook of the Use of Force in International Law (Oxford University Press 2015).

Cornwell A, 'Ethiopian, Eritrean Leaders Sign Peace Agreement in Jeddah (Reuters, 16 September 2018).

Crawford J, The Creation of States in International Law (2nd edn, Clarendon Press 2006).

Cukwurah A, The Settlement of Boundary Disputes in International Law (Manchester University Press 1967).

Dias A, 'An Inter-State War in the Post-Cold War Era: Eritrea-Ethiopia (1998-2000)' (A thesis submitted for the degree of Doctor of Philosophy in International Relations, London School of Economics, 2008).

Dinstein Y, War, Aggression and Self-Defence (3rd edn, Cambridge University Press 2001).

Gardam J, Necessity, Proportionality and the Use of Force (Cambridge University Press 2009). Gebrekidan S, 'Ethiopia and Eritrea Declare an End to their War' (New York Times, 9 July 2018).

Gilkes P and Barry T, 'The War Between Ethiopia and Eritrea: Despite claims to the contrary, Ethiopia and Eritrea have been fighting not over a border but over rival hegemonic claims in the Horn of Africa and over "national pride" and "territorial integrity"' (Institute for Policy Studies, 11 October 2005) <https://ips-dc.org/the_war_between_ethiopia_and_eritrea/>.

Gray C, 'The Eritrea/Ethiopia Claims Commission Oversteps Its Boundaries: A Partial Award?' (2006) 17(4) European Journal of International Law 699-721.

Gray C, International Law and the Use of Force (Oxford University Press 2018).

Green L, The Contemporary Law of Armed Conflict (Manchester University Press 2008).

Greenwood C, 'Self-Defence', in R Wolfrum (ed), The Max Planck Encyclopedia of Public International Law (Oxford University Press 2012).

Hill N, Claims to Territory in International Law and Relations (Oxford University Press 1945). Klein N, 'Claims Commission' in Max Planck Encyclopedia of Public International Law (online edition, updated 2013).

Kohen M and Hebie M, 'Territory, Acquisition' in Max Planck Encyclopedia of Public International Law (online edition, updated 2011).

Kritsiotis D, 'Topographies of Force' in Schmitt M and Pejic J (eds) International Law and Armed Conflict: Exploring the Faultlines: Essays in Honour of Yoram Dinstein (BRILL 2007). Lata L, 'The Ethiopia-Eritrea War' (2003) 30(97) Review of African Political Economy 369388.

Lionel Cliffe, 'Regional Dimensions of Conflict in the Horn of Africa' (1999) 20(1) Third World Quarterly 89-111.

Lyons T, 'Avoiding Conflict in the Horn of Africa U.S. Policy Toward Ethiopia and Eritrea' (Council on Foreign Relations, 2006).

Marcus H, A History of Ethiopia (University of California Press 2002).

Mikanagi T, 'Establishing A Military Presence in a Disputed Territory: Interpretation of Article 2(3) and (4) of the UN Charter' (2018) 67(4) 1021-1043.

Milano E, 'Territorial Disputes, Wrongful Occupations and State Responsibility: Should the International Court of Justice Go the Extra Mile?' (2004) 3 The Law and Practice of International Courts and Tribunals 509.

Murphy SDD, 'The Eritrean-Ethiopian War - 1998-2000' in Ruys T, Corten O and Hofer A (eds), The Use of Force in International Law: A Case-Based Approach (Oxford University Press 2018). 
Murphy SDD, Kidane W, and Snider T, Litigating War: Mass Civil Injury and the EritreaEthiopia Claims Commission (Oxford University Press 2013).

Novaci G, 'The Lines of Tension in the Horn and the Ethiopia Eritrea Case' in A de Guttry and others (eds) The 1998-2000 War Between Eritrea and Ethiopia: An International Legal Perspective (Acer Press 2009) 109-223.

O'Connell ME, 'The Crisis In Ukraine 2014- ' in Olivier Corten and Tom Ruys (eds) International Law and the Use of Force: A Case-Based Approach (Oxford University Press 2018).

Paddeu F, 'Countermeasures' in Max Planck Encyclopedia of Public International Law (Online edtion, updated 2015).

Philipson, D, Ancient Ethiopia: Aksum, Its Predecessors and Successors (British Museum Press: London 1988).

Plaut M and Gilkes P, 'Conflict in the Horn: Why Eritrea and Ethiopia are at War' (Briefing Paper, Chatham House 1999) <https://reliefweb.int/report/eritrea/conflict-horn-why-eritreaand-ethiopia-are-war>.

Plaut M, 'The Conflict and its Aftermath' in Gilkes P and M Plaut (eds) War in the Horn: The Conflict Between Eritrea and Ethiopia (Royal Institute of International Affairs 1999).

Prescott V and Triggs G, International Frontiers and Boundaries (BRILL 2008).

Roy S, 'Japan Throws Weight Behind India and Bhutan, Says No Side Should Try to Change Status Quo by Force', (The Indian Express, 19 August 2017).

Ruys T, 'Armed Attack' and Article 51 of the UN Charter (Cambridge University Press 2010). Sharma SP, Territorial Acquisition, Disputes and International Law (Springer 1997).

Tams C, Enforcing Obligations Erga Omnes in International Law (Cambridge Studies in International and Comparative Law 2005).

Thirlway H, 'Territorial Disputes and Their Resolution in the Recent Jurisprudence of the International Court of Justice' (2018) 31(1) Leiden Journal of International Law 117.

Waibel M, 'Falkland/Islas Malvinas', in R Wolfrum (ed), The Max Planck Encyclopedia of Public International Law (Oxford University Press 2012).

Weston B, 'Security Council Resolution 678 and Persian Gulf Decision Making: Precarious Legitimacy' (1991) 85 American Journal of International Law.

Woldemariam M, "No war, no peace" in a region in flux: crisis, escalation, and possibility in the Eritrea-Ethiopia rivalry' (2018) 12(3) Journal of Eastern African Studies 407-427.

Yiallourides C, M Gehring and J-P Gauci, The Use of Force in relation to Sovereignty Disputes over Land Territory (BIICL 2018).

Yihdego Z, 'Ethiopia's Military Action Against the Union of Islamic Courts and Others in Somalia: Some Legal Implications' (2007) 56(4) International and Comparative Law Quarterly 666-676.

Zewde B (ed), A Short History of Ethiopia and the Horn (Addis Ababa University, 1998). 